\title{
Profiles in Intelligence: An Interview with Michael Herman
}

\section{Mark Phythian}

\section{Introduction}

Michael Herman is a pioneer of the academic study of intelligence. His career has spanned the worlds of intelligence and academia in the United Kingdom, and done much to bring the two closer together. Born in 1929, Michael was educated at Scarborough High School before securing a scholarship to read Modern History at Queen's College, Oxford, in 1946. His studies there were interrupted by two years' National Service between 1947 and 1949, when Michael served in the Intelligence Corps in Egypt. He then returned to Oxford to complete his studies and was awarded a $1^{\text {st }}$ class degree. In 1952 he joined the Government Communications Headquarters (GCHQ) based in Cheltenham, where he was to remain in a succession of roles until 1987, a period that also included secondments to the Cabinet Office, as Secretary of the Joint Intelligence Committee, and to the Defence Intelligence Staff.

On his retirement from GCHQ in 1987, Michael moved to Nuffield College, Oxford initially as a Gwilym Gibbon Research Fellow, and it was here that he began to work on what would become his landmark study of intelligence organisations, roles and effects, Intelligence Power in Peace and War. This was published by Cambridge University Press and the Royal Institute of International Affairs in 1996. On publication, Professor Christopher Andrew called it, "the best overview of the nature and role of intelligence that I have read. It is surely destined to become a standard work." This was a prescient comment, as Intelligence Power quickly established itself as a key reference point for all those seeking to study the nature, roles and impact of intelligence as a state function, influencing a whole generation of academics drawn to its study. 
Michael has continued to publish regularly and promote the study of intelligence ever since. He was the founding Director of the Oxford Intelligence Group, which provided a valuable space in which to discuss intelligence and played a role in bringing together practitioners and academics. His recommendations for the future of the British system of intelligence appeared in 1997 as a Centre for Defence Studies publication and elsewhere. He gave evidence to the Butler review of intelligence into weapons of mass destruction in the wake of the 2003 invasion of Iraq which influenced the review group's recommendations around improving professional intelligence standards and training. A collection of his academic articles was published as Intelligence Services in the Information Age: Theory and Practice by Frank Cass in 2001. More recently he has co-edited and contributed to a special issue of this journal, Intelligence in the Cold War: What Difference Did It Make? Subsequently published as a book, this collection posed key questions about the role of intelligence in the conflict that had dominated Michael's career in intelligence, and reflected his deep interest in intelligence history and firm belief that theory needs to be grounded in thorough historical research.

Apart from his lengthy Associateship at Nuffield, he has been an Honorary Departmental Fellow in the Department of International Politics at Aberystwyth University and a Senior Associate Fellow of St. Antony's College, Oxford and has had other relationships elsewhere at home and abroad. In 2005, Michael was made an Honorary Doctor of Letters by the University of Nottingham and in June 2016 received the Lifetime Achievement Award from the International Association for Intelligence Education (IAFIE). 


\section{Interview}

What follows is the edited transcript of an interview conducted with Michael Herman at Nuffield College, Oxford, on $10^{\text {th }}$ March 2016.

\section{MP: Your book, Intelligence Power in Peace and War, is a landmark work in the study of intelligence. Can I begin by asking you how and why you came to write it?}

MH: When I finished reading History here in Oxford in 1952 I was torn between trying to be an academic and going into the civil service. Then GCHQ offered a job interview via my tutor, John Prestwich, a medieval historian who had been a distinguished member of wartime Bletchley Park. GCHQ were starting to recruit cadets as 'managerial types' rather than potential technical experts, and Prestwich suggested that I should apply. This innovation in GCHQ's recruitment may have owed something to (Sir) Eric Jones who became its Director in 1952. He had originally left school at 16 and established his own company in the wool trade, and was very much a managerially-inclined, non-specialist leader. So two of us were recruited as the new, and controversial 'managerial types.' We had an unhappy first year; the other chap left; I realized that I did not have Sigint's professional talents; and I was all set to come back to Oxford at the end of my first year. However, I was given a more interesting job and had started playing for the office rugby team, and I decided to stay. So there was an element of accident about it, but I had a thoroughly enjoyable career and have no regrets about it. Among the interesting jobs I did was to be Secretary of the Joint Intelligence Committee (the JIC) in the Cabinet Office in London in 1972-75; and a few years later I was put in charge of our Soviet and Warsaw Pact Division, running nearly a thousand people in Cheltenham and half our collection resources worldwide, and with all the American and other foreign contacts this entailed: 
the sort of job you dream about. I did it for five years, and other jobs afterwards. But from my Cabinet Office tour I had got interested in the intelligence community as a whole and the big questions about it, and had developed a hankering to think and write about it academically, and this became my retirement.

\section{MP: During the period when you were rising up the ranks at GCHQ was there an intelligence literature that you could draw on?}

MH: No, we didn't read books. For most of the time there was little serious intelligence literature - the first volume of Hinsley's official history of intelligence in the Second World War was published in $1979^{1}$ and others followed soon afterwards, but these were late in the day as far as I was concerned - and the prevailing attitude anyway was that intelligence books were dangerous and discouraged. The institutional wisdom of past experience was passed down inside the organization, so we learned something about wartime Bletchley and its successes. But for most of my time there was no serious literature and no particular reason for looking for it.

\section{MP: It wasn't encouraged?}

MH: On the whole, not. The highly classified wartime histories were of course available, but locked away in cupboards: and who could spend his working hours delving into past history? When I was running the Soviet effort I tried to get people to read more of the published Western literature about Soviet military forces, but even this was not altogether straightforward when, until 1983, GCHQ was still supposed to be doing something quite different. Part of the culture of

\footnotetext{
${ }^{1}$ F. H. Hinsley, with E. E. Thomas, C. F. G. Ransom \& R. C. Knight, British Intelligence in the Second World War: Its Influence on Strategy and Operations. Volume 1 (London: HMSO, 1979).
} 
secrecy in any case is that the office is something that you leave behind when you go home.

MP: What you did after retirement from GCHQ was a radical departure at the time. It certainly wasn't the norm to make this transition from practitioner to academic commentator, so you were a trailblazer in a way?

MH: Yes, I was and I was a fortunate trailblazer, because the senior members of GCHQ who had to deal with my academic plans had all worked for me and were personal friends, and they fell over backwards to be kind and let me do what I wanted. It was all carefully documented in an agreement with the Cabinet Office that I would to submit everything for official clearance, and a result was that what I wrote had to be academic stuff with very little personal element. Having been involved at times in discouraging potential intelligence authors I was familiar with the official sensitivities, so there were few problems about clearance for what I submitted. But I was lucky: all those involved could have been much more difficult, particularly since Mrs Thatcher through the 1980s was taking a strong line against all intelligence publications.

MP: So you have now left GCHQ and you are working on what will become Intelligence Power in Peace and War from 1987 onwards. At this point is there a literature out there that you draw on that inspires you, because one of the notable things about the book is the way in which you combine literatures on military history, strategic studies, international relations, and public administration. What were the key things that influenced you at the time?

MH: There was certainly good intelligence history. Chris Andrew was already publishing; ${ }^{2}$ the Hinsley official histories were becoming available; R V Jones

\footnotetext{
${ }^{2}$ For example, Christopher Andrew and David Dilks (eds.), The Missing Dimension: Governments and Intelligence Communities in the Twentieth Century (London: Macmillan, 1984); Christopher Andrew, Secret
} 
had produced his account of wartime technical intelligence. ${ }^{3}$ What is now the academic London Study Group was meeting from around 1982 or 1983. (I remember that while still working I wanted to go to one of their first conferences, and met with a quite passionate appeal from my security colleague not to let the side down by going). On intelligence's political science and international relations aspects there was less available, but there were the American books of the 1970s and 1980s on warning failure and World War II deception, based on the much earlier study of Pearl Harbor ${ }^{4}$ and fuelled of course by the Cold War's constant worry of warning failure of a Soviet attack.

\section{MP: I guess that in the US there would have been an emerging literature on oversight and accountability, but that would have been outside your focus?}

MH: Yes. Loch Johnson was already producing his studies of American intelligence's legality and accountability ${ }^{5}$ but I consciously decided to avoid such issues. There was no guarantee that I would get approval for publishing anything, and adding these to the issues discussed would increase the hazards. They were also not as prominent as they became later: the British community had not acquired its full legal status, and as a country we had not yet acquired the American fixation with problems of legality and oversight. With hindsight it was a major omission from the book, but perhaps I was really not sufficiently interested. My interests were (perhaps still are) those of a large-scale production manager who worries about making his product as accurate and useful as possible, and not those of a liberal lawyer.

\footnotetext{
Service: The Making of the British Intelligence Community (London: William Heinemann, 1985). In addition, Christopher Andrew was a founding editor of this journal, which first appeared in 1986.

${ }^{3}$ R. V. Jones, Most Secret War: British Scientific Intelligence 1939-1945 (London: Hamish Hamilton, 1978).

${ }^{4}$ Roberta Wohlstetter, Pearl Harbor: Warning and Surprise (Stanford, CA: Stanford University Press, 1962).

${ }^{5}$ For example, Loch K. Johnson, A Season of Inquiry: The Senate Intelligence Investigation (Lexington, KY:

University of Kentucky Press, 1985).
} 


\section{MP: So, the production of the book, from moving to Oxford and beginning to think about it to actually publishing the book, was a period of eight or nine years?}

MH: Yes. I was worried for a long time that as an academic, or quasi-academic, I ought to be producing theory and didn't seem to be doing so. I now think of the book as a thoughtful textbook, but that originally seemed too prosaic. But it took shape eventually, helped by invitations to talk about intelligence in Oxford and elsewhere.

The fact that I was based on Nuffield College for most of this work was also fortunate. For my first year the college gave me a fellowship originally created for civil servants in mid-career - far removed from my situation - and it was subsequently generous with an associate membership. I also had a later spell running seminars at St Antony's which developed into the Oxford Intelligence Group that still continues at Nuffield. Apart from anything else the Nuffield connection in the early days acted as an indication of respectability, at a time when any insider trying to write about intelligence would be suspected of being a whistleblower.

The book itself was also positively backed by Chatham House, through Admiral Jim Eberle, ${ }^{6}$ whom I had met in my GCHQ days and was running it in his retirement, and his deputy John Roper. ${ }^{7}$ In their support for the book they were keen on convening an invited Chatham House study group to comment on draft chapters as they were written. The idea was put to the Foreign Office for

\footnotetext{
${ }^{6}$ Admiral Sir James Eberle, GCMG, (1927-) formerly Commander-in-Chief Fleet and Commander-in-Chief Home Command.

${ }^{7}$ Lord Roper of Thorney Island (1935-2016) was a Labour Party MP from 1970 who defected to the newlyformed Social Democratic Party in 1981, serving as a SDP MP and the party's Chief Whip until 1983. After leaving the House of Commons he took up a senior staff role at the Royal Institute of International Affairs (Chatham House) in 1984. He was created a life peer in 2000.
} 
comment - a reminder of the period's sensitivities - and encountered objections, and eventually John Roper accepted the condition that no current or retired intelligence practitioners would be invited. So it was an odd body for its purpose, made up substantially of former diplomats who had been users of intelligence but not producers. In practice it was useful to have the drafts picked over in this way by the great and the good, particularly by the brilliant but acerbic Reginald Hibbert. ${ }^{8}$ I had hitherto thought that I was reasonably adept with bureaucratic prose and intelligence reports, but his comments made me decide to develop a new style of writing.

MP: The book was published in 1996 and it appeared it the midst of the postCold War debate about the future of intelligence and whether or not there should be a peace dividend that extended to intelligence. So the intelligence landscape has changed an awful lot from 1996 to the present day. How would you characterise the nature and extent of the changes to intelligence, as either a function or a set of practices, between then and now?

MH: One major change has of course been the major technical source of material on the internet, which didn't exist in my day. More important, perhaps, have been the changes in targets, above all the priority for counterterrorism and its targets of individual people and not things. It must be so different from our old concentration on Soviet military forces and their weapons. I suppose the other big change since the 1990-1 Iraqi War has been the extensive support for active military operations: intelligence for war rather than peace. I guess that this, like counterterrorism, has had a much bigger tactical component than was usual in my

\footnotetext{
${ }^{8}$ Sir Reginald Hibbert (1922-2002) served in the Special Operations Executive (SOE) during the Second World War before joining the Foreign Service where he held numerous posts, culminating in his appointment as Ambassador to France. After retiring, in 1982 he became director of the Ditchley Park Foundation. His notable lecture on 'Intelligence and Policy', given in Oxford in 1989, was published in Vol.5 No.1 (January 1990) of this journal, pp.110-28.
} 
day, when field units were mainly reporting back to the centre and the effects on decisions were at the London level. What the Russians were doing was rarely of immediate tactical concern, but contributed to the strategic picture of Soviet intentions and capabilities. Post-1990 support for military operations must involve more devolution towards the front line, and the same must be true of counterterrorist support to the police. Yet central government gets involved in tactical decisions as well as strategic ones, so the whole thing has to be a carefully orchestrated balance between the field and the centre.

The other difference, of course, is the huge change in intelligence's legal situation and public persona, which were so different in my experience. Ministerial approval for some things was then taken seriously - as seriously as it is taken now - but for our attitudes to it I treasure a colleague's description of it in counterterrorism as 'the procedures designed to turn our sprint into a hurdle race.'

\section{MP: And from a foreign intelligence perspective boundaries were much clearer in the Cold War era, whereas boundaries are much more indistinct and permeable post-Cold War?}

MH: I guess so. Of course not everything was part of the Cold War, and there was competition from very different targets. I recall our problem in the Cabinet Office when Sir Leonard Hooper arrived as Intelligence Coordinator and in revising the JIC's annual guidance sought to specify whether the highest priority target was the huge Soviet Union or the relatively tiny IRA. He eventually put them as equal priority. It is the sort of question that still interests me: what are these intelligence formalities designed to achieve and what difference do they actually make? 
MP: One other transformation involves the extent to which intelligence is truly global now, whereas big states invested in it heavily during the Cold War, but not everyone did in any large way.

MH: Yes, every country now has a security organisation of some kind and I imagine that for many of them the prime requirement is to keep the regime in power. Even if this is not the case the primacy of counterterrorism must have changed the shape of national intelligence everywhere, including the balance inside it. Until recently almost all our JIC chairmen were Foreign Office or exForeign Office officials, but the last two have come from elsewhere. In this same period two former Directors General of the Security Service have recently been rewarded in retirement with promotion to the House of Lords, a sign where modern intelligence most counts.

MP: And in many ways the September 11, 2001 terrorist attacks are the pivot. You published an article on these in the following year, which posed the question '11 September: Legitimizing Intelligence?' How far, in retrospect, do you think it did and in what ways, and why was there a need to legitimise intelligence? The title seemed to suggest that in 2001 there was a question of legitimacy, which may have been the post-Cold War debate about whether that scale of operation was necessary?

MH: I think I assumed that September 11 would eliminate the debate about intelligence methods and individual liberty: at bottom, perhaps, a debate whether this particular counterterrorist campaign is war or policing. As you'd expect I tend to think of it as a variant of war, but I am critical of the international lawyers who have failed to develop proper concepts for this sort of conflict. It must worry intelligence's current practitioners. In my experience the job takes on a different hue when people feel they are saving lives. This applied to the national effort 
against the IRA, and also to our GCHQ involvement in the Falklands War, when the full-time effort involved was relatively small in numbers but somehow transformed the whole department with the psychology of war and not peace. It must be difficult for people nowadays to have a constant eye on what the lawyers will allow them to do.

This leads me to add that I would like someone to do a follow-up to my comments in Intelligence Power on the effects of secrecy on people and organisations: what's special about secret organisations and the people in them? Some years ago the CIA commissioned an anthropologist to study its analysts ${ }^{9}$, but otherwise it has not been looked at in any detail, and I would like to see it properly tackled.

\section{MP: And what's the answer?}

$\mathrm{MH}$ : The answer I suggested in the book was that secrecy makes for high morale. Even in my time people at GCHQ felt a sense of difference, of being secret and somehow 'special'. In fact it was dealing largely with peace and not war, but in the background there was always the risk of the nuclear war which we felt we were there to prevent. GCHQ tried hard to behave as a normal government department, but most people did not embrace the image of the conventional civil servant and preferred to think that they were 'different' (as indeed they were). A downside was of course that the idea of 'difference' could produce unrealistically high expectations which could turn into powerful disappointments if they were not realized amid the normal rough-and-tumble of organizational management: some of the reactions to GCHQ's de-unionisation in 1984 probably fell into this category.

\footnotetext{
${ }^{9}$ Rob Johnson, Analytic Culture in the US Intelligence Community (Washington, DC: Center for the Study of Intelligence, 2005).
} 
MP: Thinking about national systems in terms of concentric circles, as you do in Intelligence Power in Peace and War, seems to me to still offer a very good way of approaching comparative analysis. Could you explain that idea and how the detail of the different circles might look today?

MH: I was baffled for long time about how one should write about types of organizations in academic terms, when the individual examples are so variable in form, effectiveness and everything else. I read bits of Weber about 'ideal types' and dabbled in other organizational writers, but the idea of the three concentric circles was the only way I could find of describing what I was doing. But what I wrote was still very UK-US centred. I hope for example that someone will soon come up with a competing concept of European 'continental intelligence'; and this might only be a start for developing other cultural and regional models.

MP: There has been considerable discussion of the European Union as an intelligence actor. In your view, what are the possibilities and limitations regarding an $\mathrm{EU}$ intelligence role? Is this something we should welcome?

MH: SIGINT has certainly produced the exclusivity of the Five Eyes alliance. World War II was fought by a multinational alliance but intelligence remained a UK-US prerogative, substantially because of the Bletchley dimension, as in the exclusion of the exiled French and Polish governments from all its output. In the Cold War the Soviet espionage threat produced the similar barrier in NATO between the top drawer, CANUKUS intelligence product and all the lower category material; and much of this seems to have continued afterwards.

At the top level I am disappointed that there hasn't been a NATO JIC or something of the kind. It is strange that the Americans, Canadians and Australians contribute to some JIC assessments and attend appropriate parts of the meetings, and yet France, Germany, also Japan - the big powers - are almost 
totally excluded. Though I understand the practical reasons, it's a pity that a European forum of some kind hasn't emerged - in response to the Ukrainian situation, for example.

MP: One of your key areas of interest has been the role of intelligence in the Cold War. You have highlighted one easily overlooked intelligence contribution to a peaceful outcome - the way in which intelligence provided reassurance. Would you say this was ultimately the most important contribution of intelligence in the Cold War?

MH: I think it was important. The psychology of the Cold War on both sides was so fertile for exaggeration that anything that brought the threat assessments towards reality was helpful. In two chapters in our recent Cold War book ${ }^{10} \mathrm{I}$ argued that Western intelligence reassured its governments that the feared Soviet attack was not about to be launched, but that it also scared the Soviet leadership by the intrusive collection methods it employed to get this intelligence before the American satellite photography became available.

MP: Western intelligence assessments of Soviet military strength came to be quite accurate as the Cold War evolved.

$\mathrm{MH}$ : Yes, and even in the earlier days they could have been worse. It is often written that the West was virtually blind through the 1950s, yet even then it did well in reconstructing the complete Soviet order-of-battle. One wonders what conclusions governments would have reached about the threat if these estimates had not been available. Nevertheless, the sources at that time were still mainly inferential, non-textual ones that lacked the insights that come from access to

\footnotetext{
${ }^{10}$ Michael Herman \& Gwilym Hughes (eds.), Intelligence in the Cold War: What Difference did it Make? (Abingdon: Routledge, 2013).
} 
documents, messages and conversations. From the non-textual sources it was concluded that the peacetime Soviet army was made up of 170 divisions, without realising for a long time that most of them were skeleton formations to be manned on mobilization. I argued in Intelligence Power that most intelligence sources can be divided into textual and non-textual ones, with the former tending to be the richer; and at this stage of the Cold War the non-textual ones predominated. Subsequently of course the whole picture was enriched when the American imagery became available and the targets for the first time could be seen and measured, and the data played against what was known from the other sources. Intelligence on the Soviet forces acquired a depth and confidence that it had not had previously.

\section{MP: At the same time, the question of Soviet intentions remained quite opaque. Was this a serious shortcoming or was it unrealistic to expect intelligence to be able to deliver on this?}

MH: It certainly was a serious shortcoming that there was never a clear answer to the question posed at the beginning of an early JIC report ${ }^{11}$ : 'What is Russia trying to do?' But did the tightly-drawn, conspiratorial Soviet regime ever define its long-term objectives realistically, beyond survival? Does any government?

Yet the Soviet system wrote things down, and a top-level defector or access to central documents, or a combination of both, would have provided better access than intelligence obtained. It was its bad luck that it never managed this kind of access, but against the power of Soviet secrecy this was hardly a culpable failure. Intelligence was guessing like everyone else, and deducing Soviet intentions from the scale of its capabilities; though I suspect that a particular weakness of the Whitehall system was that those who were writing the Soviet estimates did not

\footnotetext{
11 Russian Interests, Intentions and Capabilities, JIC(48)9(O)Final, 23 July 1948, London: India Office Library and Records, L/ WS/1/1173, (now in the British Library), first paragraph of Annex I, the summary.
} 
have full access to the Western action being taken against the USSR, principally by the Americans: the intrusive intelligence flights, the penetrations of territorial waters, the maritime cable-tapping, the extensive information warfare, and of course the conclusion drawn from them of Western motives. If assessments are seeing things through the target's eyes, those writing them need all the information it draws on, and those doing the job in Whitehall probably lacked some of it.

MP: You have also posed the key question relating to intelligence and the Cold War: 'what difference did it make?' How would you answer this question now?

MH: Ducking the question slightly, you need studies of comparative Cold War psychology on both sides, which I don't think exist. We thought the Cold War was all-pervading to an extent that is forgotten now, because the war never happened and we now think there was not much sustained risk of it. Yet war breaks out in the unexpected circumstances, and I suggest that intelligence in this case made the West's actions more rational, less error-prone than they might have been. I have no idea whether Soviet intelligence worked in any comparable way within the regime of which it was such an integral part. Those are my answers, but the historians need to work properly at the questions.

MP: And there were, of course, individual episodes in the Cold War where the role of intelligence, particularly in some cases British intelligence, may have been crucial. Len Scott's piece on Able Archer ' $83^{12}$ highlights one, for example.

\footnotetext{
12 Len Scott, 'Intelligence and the Risk of Nuclear War: Able Archer-83 Revisited', Intelligence and National Security, Vol.26 No.6 2011, pp.759-777. Reprinted in Herman \& Hughes (eds.), Intelligence in the Cold War.
} 
MH: My friend Harry Burke had been my deputy in GCHQ’s Soviet Division and chief Soviet expert: I much respected his expertise and had worked for two or three years to get him made my deputy. After the appearance of the Nicoll report on the JIC's warning failures ${ }^{13}$ and the experience of the Falklands War, Sir Antony Duff as JIC Chairman got Harry drafted to the committee's Assessments Staff in 1982 to boost its warning performance, and it was really he who subsequently discovered the Able Archer scare of November 1983. Oleg Gordievsky had told London of the KGB's intelligence alert, but it was Harry who looked at the technical intelligence reports of the time and noticed signs of a Soviet military alert, though spotty ones. He had to fight to get his conclusion through a sceptical JIC, but the committee's eventual report on it had its effect on UK and US governments' attitudes.

\section{MP: You gave evidence to the Butler review ${ }^{14}$ established in the wake of the 2003 invasion of Iraq and controversy over the case for war, particularly in relation to weapons of mass destruction. What would you say are the key lessons of the Iraq episode for intelligence collectors, analysts and managers, and for politicians?}

MH: This was the only time I seriously went public. It was in a Panorama programme about it. Judging whether Saddam had operational WMD in 2002-3 was exactly the same as deciding in 1959-61 whether the West was then threatened with operational Soviet missiles. I was asked to give evidence to the Butler Committee, and I suggested to them that they should not worry about the JIC itself but concentrate on the subsidiary Current Intelligence Groups where the

\footnotetext{
${ }^{13}$ See, Michael S. Goodman, 'Avoiding Surprise: The Nicoll Report and Intelligence Analysis', in Robert Dover \& Michael S. Goodman (eds.), Learning from the Secret Past: Cases in British Intelligence History (Washington, DC: Georgetown University Pres, 2011), pp.265-92).

${ }^{14}$ Lord Butler, Review of Intelligence on Weapons of Mass Destruction (HC 898; London: The Stationery Office, July 2004).
} 
judgments are formulated; and I recommended some training for this top level of assessment. This was taken seriously and some serious training has been introduced. But I also pointed out that the aim of creating the Assessments Staff in 1968 had been to make assessment more 'professional', and this had not happened: the main weight has been borne instead by secondments from policy departments. Altering this situation needs changes in the careers and status of the analysts in the Defence Intelligence Staff and the creation of a bigger analyst class, and on these little has happened. So we have the oddity that the product of our highly professional intelligence community still depends substantially for its assessment for top government on policy officials seconded for single intelligence tours.

\section{MP: What would you say are the key areas where we still need to improve our knowledge and understanding of intelligence? What are the most important gaps that scholars should be looking to fill?}

MH: There are so many avenues for exploration, but I'll limit myself to two of them. One is to make intelligence studies properly worldwide, to understand for example how it is that the British and Chinese have very different intelligence organizations in their different settings, yet both are felt to have an activity in common. The other is to develop links with other parts of public administration, particularly with studies of governments' other knowledge systems. I am struck for example by the parallels in the evolution and organization of intelligence and government statistics, and I hope people will develop comparisons of this kind.

\section{MP: Thank you very much for your time.}




\section{Michael Herman - A Select Bibliography}

'Intelligence and the Assessment of Military Capabilities: Reasonable Sufficiency or the Worst Case?', Intelligence and National Security, Vol.4 No.4, 1989, pp.765-99.

'Intelligence and Policy: A Comment', Intelligence and National Security, Vol.6 No.1, 1991, pp.229-39.

'Intelligence Warning of the Occupation of the Falklands: Some Organisational Issues', in Alex Danchev (ed.), International Perspectives on the Falklands Conflict (London: Macmillan, 1992), pp.153-164.

'Assessment Machinery: British and American Models', Intelligence and National Security, Vol.10 No.4, 1995, pp.13-33.

Intelligence Power in Peace and War (Cambridge: Cambridge University Press/Royal Institute of International Affairs, 1996)

British Intelligence Towards the Millennium: Issues and Opportunities, Centre for Defence Studies Paper No.38 (London: Brassey’s for the Centre for Defence Studies, 1997).

'Up from the Country: Cabinet Office Impressions 1972-75', Contemporary British History, Vol.11 No.1, 1997, pp.83-97.

'Diplomacy and Intelligence', Diplomacy and Statecraft, Vol.9 No.2, 1998, pp.122.

'Cold War Naval Intelligence', in Ken Booth (ed.), Statecraft and Security: The Cold War and Beyond (Cambridge: Cambridge University Press, 1998), pp.9398.

'Intelligence Services and Ethics in the New Millennium', Irish Studies in International Affairs, Vol.10, 1999, pp.249-65. 
'Modern Intelligence Services; Have They a Place in Ethical Foreign Policies? In Harold Shukman (ed.), Agents for Change: Intelligence Services in the TwentyFirst Century (London: St. Ermin’s Press, 2001), pp.287-311.

Intelligence Services in the Information Age: Theory and Practice (London: Frank Cass, 2001)

The Role of the British Joint Intelligence Committee: An Historical Perspective, published 2001 by Norwegian Institute for Defence Studies (ed.) Lars Christian Jenssen) as the proceedings of the XXVI International Colloquium of Military History on Intelligence after World War II, August 2000, pp.25-39.

‘11 September: Legitimizing Intelligence?’, International Relations, Vol.16 No.2, 2002, pp.227-41.

'Intelligence Doctrine for International Peace Support', in Ben de Jong, Wies Platje, Robert David Steele (eds.), Peacekeeping Intelligence: Emerging Concepts for the Future (Oakton, VA: OSS International Press, 2003), pp.15770.

'Threat Assessments and the Legitimation of Policy?' Intelligence and National Security, Vol.18 No.3, 2003, pp.174-8.

'Intelligence's Future: Learning from the Past', Journal of Intelligence History, Vol.3 No.2, 2003, pp.1-8.

'Counter-terrorism, Information Technology and Intelligence Change', Intelligence and National Security, Vol.18 No.4, 2003, pp.40-58.

'Ethics and Intelligence after September 2001', Intelligence and National Security, Vol.19 No.2, 2004, pp.342-58.

'Intelligence and the Iraqi Threat: British Joint Intelligence after Butler', RUSI Journal, Vol.149 No.4, August 2004, pp.18-24. 
“The Customer is King': Intelligence Requirements in Britain', in Loch K. Johnson (ed.), Strategic Intelligence, Volume 2: The Intelligence Cycle (Westport, CT: Praeger Security International, 2007), pp.165-80.

'Intelligence as Threats and Reassurance', Intelligence and National Security, Vol.26 No.6, 2011, pp.791-817.

'What Difference Did It Make?’ Intelligence and National Security, Vol.26 No.6, 2011, pp.886-901.

Intelligence in the Cold War: What Difference Did It Make? (Abingdon: Routledge, 2013) - co-edited with Gwilym Hughes, originally published as a special issue of Intelligence and National Security, Vol.26 No.6, 2011.

'The Post-War Organization of Intelligence: The January 1945 Report to the Joint Intelligence Committee on “The Intelligence Machine”, in Robert Dover \& Michael S. Goodman (eds.), Learning from the Secret Past: Cases in British Intelligence History (Washington, DC: Georgetown University Press, 2011), pp.11-42.

'Intelligence in the Cold War: Did it Matter?' in Carlos Collado Seidel (ed.), Geheimdienste, Diplomatie und Krieg: Das Raderwerk der Internationalen Beziehungen (Festschrift for Wolfgang Krieger) (Berlin: Lit Verlag, 2013), pp.55-69. 